\title{
CYTOGENETICAL AND BIOCHEMICAL EVALUATION OF DIFFERENT GENOTYPES OF STEVIA PLANTS USED AS A NATURAL SWEETENER \\ Khattab, Amira E. ${ }^{1}$; M. E. El-Zaidy ${ }^{2}$ and A. B. Doaigey ${ }^{2}$ \\ ${ }^{1}$ Dept. of Biology Fac. Of Education, Elmajmaah Univ., Saudi Arabia. \\ ${ }^{2}$ King Saud Univ., Fac. of Sci., Dept. of Botany and Micro., Al Riyadh, Saudi Arabia.
}

\begin{abstract}
Seven Stevia (Stevia rebaudiana Bertoni) genotypes were investigated in this work. In order to achieve such a purpose, chromosome behavior at mitosis as well as at meiosis, pollen fertility, their content of the amino acid proline, and some agronomic traits were precisely studied. The obtained results showed that the chromosome number is $2 n=22$ as mitotic examination revealed and 11 bivalents as indicated by meiosis were observed at diakinesis . number of branch ranged from 4 to 12, plant height from 8.3 to $28.6 \mathrm{~cm}$ and number of leaves ranged from 9.3 to 17.2 , Number of heads ranged from 1.1 to 4.2 . The amino acid proline ranged from 1.18 to $8.2 \mathrm{mg} / \mathrm{g}$ dry leaves. Stickiness of chromosomes and presence of 2-3 nucleoli / cell might be indicated that this genotypes are a result of polyploidy.
\end{abstract}

Keywords. Stevia rebaudiana, morphological, chromosome stickiness and tappetum.

\section{INTRODUCTION}

Stevia rebaudiana Bertoni, is one of the new world genera of the family compositae and is related to Sunflower and Chicory. The number of species within this genius is ranged from 150 to 300 (King \& Robinson,1972). Stevia combins with other herbs to enhance the nutritive values (Soejarto et al., 1982 ; David 1996 and El Sharnoby, 2009).

It is a perennial herb belonging to the Asteraceae family The leaves of Stevia are source of diterpene glycosides, such as stevioside and rebaudioside $A$ and $C$ which are estimated to be 110-270 times sweeter than sucrose (Uddin et al. 2006; Megeji et al. 2003 and El Sharnoby, 2009 ). Stevia products have some advantages from a food technology stand point, it has no calories, and so it is suitable for diabetics, don't cause tooth decay, is a heat stable for cooking and baking, easily soluble in water, stable in foodstuffs and natural sweetener. These glycosides are extracted and refined from plants without chemical or enzymatic modifications. On the other hand, Stevia has several properties over other sweeteners, it combines with other herbs to enhance the nutritive values (Seehy, 2003and El- Sharnoby, 2009). Originally, the natural of Stevia is Paraguay.. The number of species within this genus ranges from 150 to 300 (King and Robinson, 1972 and $\mathrm{El}$ Sharnoby, 2009).

Today the use of products and extracts of Stevia is widespread throughout the world. The extracts of Stevia are used in China, Taiwan, Thailand, South Korea, Brazil, Malaysia, Indonesia, Argentina, Paraguay, Philippines, and Vietnam (Soejarto et al 1982, and David 1996). The extracts also are used in some arabic countries (eg. Egypt and Saudia Arabian) 
Egypt, in 1994 has registered Stevia as natural sweetener for use in food and pharmaceutical products. The main advantage of Stevia use as natural sweeteners is for diabetics.

This study, however, was planned to determine the chromosome number and behaviour, pollen fertility, proline content and some agronomic traits. Proline content in leaves was estimated as an indicator for salinity and drought tolerance.

\section{MATERIALS AND METHODS}

Materials used in this work were kindly obtained from Biotechnology Laboratory, Department of Genetics, Fac. Agric. Alexandria University and Sabbhia Experimental Station, Institute of Sugar Crops, Agricultural Research Center (ARC), Egypt.

\section{Agronomic traits}

Agronomic traits were recorded and analyzed using a Randomized Complete Block Design (RCBD) with 10 replicates for each genotype and Least Significant Difference Test (LSD) was used for comparison between means.

\section{Detremination of Proline content}

Proline content was estimated in the Central Laboratory, Faculty of Agriculture; Alexandria University. According to the procedure described by Hamilton (1962), $4 \mathrm{ml}$ of $3.5 \%$ sulfa salicylic acid were added, to one gram leaves, homogenized and centrifuged at $3000 \mathrm{rpm}$ for $5 \mathrm{~min}$. The supernatant was saved and used for proline analysis using Beckman CL Amino Acid Analyzer $119 \mathrm{cl}$.

\section{Cytological studies}

Floral buds, and root tips were collected. For cytological examination the microsporocytes (immature heads) from each genotype were collected and fixed in glacial acetic acid for one hr. and then are transferred in fresh Carnoy's for killing and fixation. The fixed materials were, then transferred to a solution of $70 \%$ ethanol and stored in a refrigerator at $4 \mathrm{C}^{\circ}$ until usage. The chromosomes stainabilitywas achieved according to (Eid 1958, 1963) and Fachinettoet al., (2008). The cytological preparations were made following the well-known aceto-carmine smear technique. Staining of pollen mother cells (PMC) was done according to the procedure described by McClintock (1929) and Darlington and La-Cour (1962). Diakinesis stages were examined to determine the total number of chromosomes and meiotic as well as mitotic stages were photographed when needed.

\section{RESULTS} results.

Regarding the tested agronomic traits (1) illustrated the observed

No. of branches: this character ranged from 4 (Genotyp-6) to 12 (genotype-1). This values means that a difference between genotypes (up to 3 fold increase was achieved.

Plant height: ranged between $8.3 \mathrm{~cm}$ to $28.6 \mathrm{~cm}$ giving avidness that more than 3.5 fold increases was detected. 
No. of Leaves: it was found to be ranged from 8.2 (Genotype -3) to 17.2 (Genotype-1). However, comparing this result, one can conclude that genotype-1 was proven to be higher in number of branch, plant height, and number of leaves. This result, however, might be taken in consideration in breeding program and in general. The genotypes 1, 4 and 5 were found to be the best in this evaluation

Table (1): Description of six characters of the seven Stevia genotypes which used in this study.

\begin{tabular}{|c|c|c|c|c|c|c|}
\hline Genotype & $\begin{array}{l}\text { No. of } \\
\text { branch }\end{array}$ & $\begin{array}{c}\text { Plant height } \\
\text { Cm } \\
\text { X } \pm \text { S.D\% }\end{array}$ & $\begin{array}{c}\text { No. of leaves } \\
\text { on branch } \\
\text { X } \pm \text { S.D\% }\end{array}$ & $\begin{array}{c}\text { Leaf length } \\
\text { Cm } \\
\text { X } \pm \text { S.D\% }\end{array}$ & 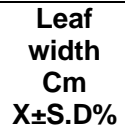 & 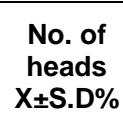 \\
\hline Genot-1 & 12 & $14.2 \pm 11.23$ & $17.2 \pm 12.98$ & $4.9 \pm 1.74$ & $2.0 \pm 0.48$ & $3.4 \pm 4.44$ \\
\hline Genot-2 & 6 & $13.3 \pm 10.97$ & $12.3 \pm 8.5$ & $4.4 \pm 1.07$ & $1.4 \pm 0.37$ & $2.1 \pm 2.67$ \\
\hline Genot-3 & 9 & $8.30 \pm 4.36$ & $8.2 \pm 4.18$ & $3.5 \pm 0.67$ & $1.5 \pm 0.44$ & $2.2 \pm 1.32$ \\
\hline Genot-4 & 11 & $28.6 \pm 11.91$ & $14.9 \pm 3.9$ & $4.2 \pm 0.70$ & $2.0 \pm 0.25$ & $4.2 \pm 2.10$ \\
\hline Genot-5 & 10 & $16.60 \pm 8.34$ & $13.8 \pm 2.39$ & $4.5 \pm 0.51$ & $2.0 \pm 0.33$ & $1.7 \pm 2.10$ \\
\hline Genot-6 & 4 & $10.8 \pm 4.44$ & $10.5 \pm 1.91$ & $4.4 \pm 0.50$ & $2.0 \pm 0.22$ & $1.7 \pm 1.14$ \\
\hline Genot-7 & 8 & $12.0 \pm 7.74$ & $9.3 \pm 3.01$ & $4.4 \pm 0.67$ & $1.6 \pm 0.32$ & $1.1 \pm 1.23$ \\
\hline
\end{tabular}

Means (X) and standard deviation (S.D\%) for number of branches, plant height, number of leaves on branch, leaf length, leaf width, and number of heads in studied genotypes of Stevia rebaudiana Bertoni.

Pollen fertility: Estimation of pollen fertility for the seven genotypes in shown in (table, 2). Pollen fertility ranged from 89.01 to 98.1 for the genotypes $5 \& 4$, respectivaly. However, this pollen fertility was not affected by Stickiness noted from the cytological examination.

Table (2): Genotypes of Stevia and pollen fertility

\begin{tabular}{|l|c|c|c|}
\hline Genotype & No. pollen grains examined & No.viable pollen grains & \% fertility \\
\hline $\mathbf{1}$ & 2340 & 2111 & 90.21 \\
\hline $\mathbf{2}$ & 3210 & 3117 & 97.10 \\
\hline $\mathbf{3}$ & 1998 & 1882 & 94.19 \\
\hline $\mathbf{4}$ & 2010 & 1972 & 98.10 \\
\hline $\mathbf{5}$ & 3002 & 2672 & 89.01 \\
\hline $\mathbf{6}$ & 2450 & 2310 & 94.28 \\
\hline $\mathbf{7}$ & 2320 & 2070 & 89.22 \\
\hline
\end{tabular}

Figures (1,2, and 3$)$ show different satges of meosis and mitosis and multinucleolei. Table (3) shows the result obtained from the estimation of proline content in Stevia leaves of the different genotypes. Proline was found to be ranged from 1.18 (genotype, 6) to 8.2 (genotype, 1). This result means that more than 7 - fold increases in proline content had achieved.

Table (3): Genotypes of Stevia and amino* acid proline

\begin{tabular}{|l|c|c|c|}
\hline \multicolumn{1}{|c|}{ Genotype } & Proline & Genotype & Proline \\
\hline 1 & 8.2 & 5 & 2.2 \\
\hline 2 & 4.1 & 6 & 1.18 \\
\hline 3 & 2.8 & 7 & 4.06 \\
\hline 4 & 4.12 & & \\
${ }^{*} \mathbf{m g} /$ g dry weight leaves & \multicolumn{3}{|c}{}
\end{tabular}


Khattab, Amira E. et al.

A

D

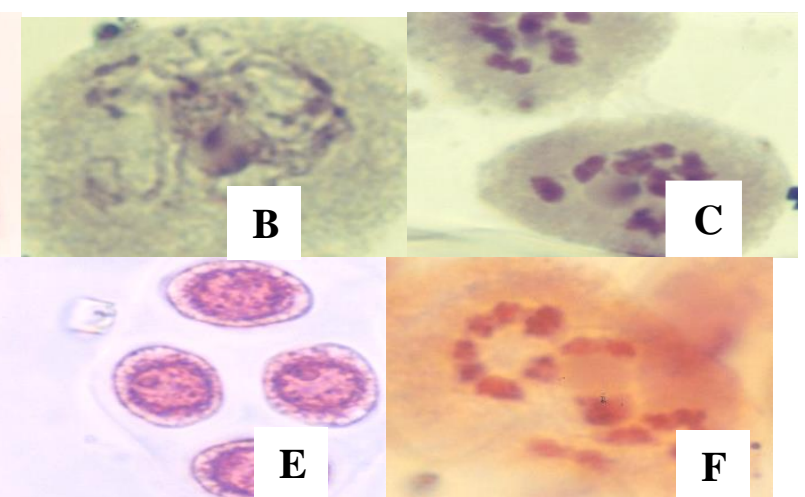

$\mathbf{E}$

Figure (1): A and B photomicrographs of Pachytene stage of meiosis with heteropycnosis of Stevia (Stevia rebaudiana), C photograph of diakinasis stage with 11 bivalents, D photograph of meiotic Telophase stage, E photomicrograph of quarted stage and in $F$ photomicrograph showing stickiness abarration to bivalents in diakinasis stage.

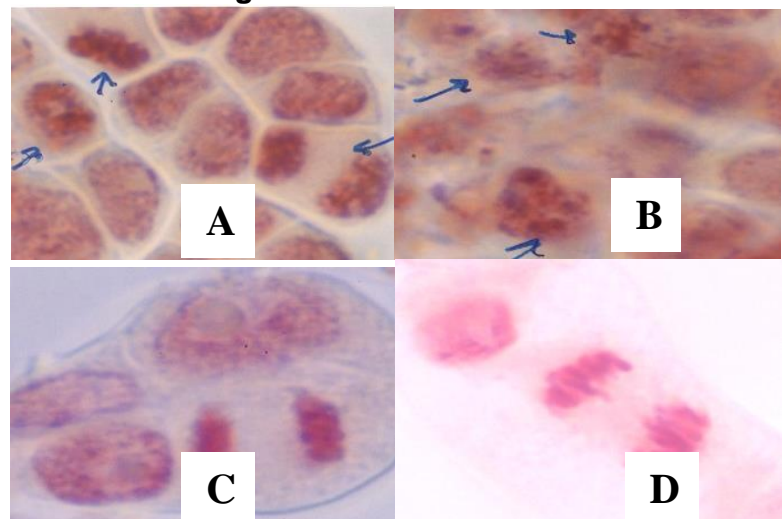

Figure (2): Photomicrographs of mitotic division stages; in cells of Tappetum layer with high mitotic activity in photomicrographs $A$ and $B$, while in C showing mitotic Telophase stage in Tappetum layer, and in D showing the Telophase stage in cells of root tip.
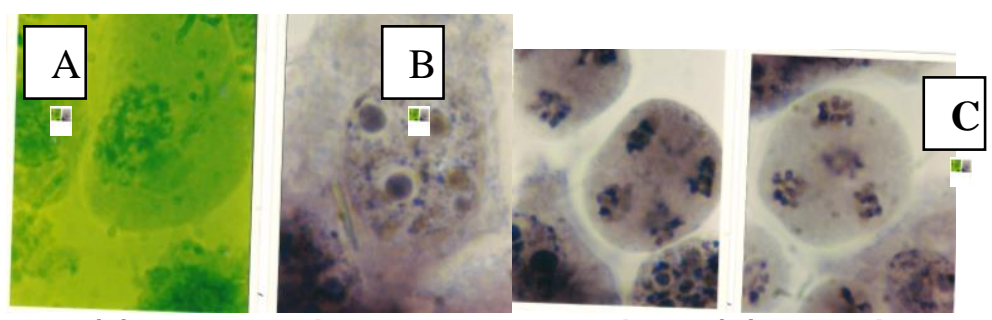

Figure (3): Photomicrographs showing (A) multinucleolei, heterochromatin and $(C)$ second telophase. 


\section{DISCUSSION}

In conclusion, the present investigation revealed that the chromosome number of Stevia is $2 n=22$ and 11 bivalents in meiosis were observed. Normal chromosome behavior with high degree of stickiness was observed with 2-3 nucleoli/ nucleolus giving an evidence that the tested genotypes are genetically different and this genotype came from polyploidy. Investigation of some agronomic traits proved that the tested genotypes are genetically different. Examination of pollen fertility revealed that this phenomenon was not affected by stickiness. It was suggested that proline is acting as a compatible cytoplasmic solute, balancing an accumulation of salts outside of the cytoplasm (Vetberg and Stewart, 2001). The results obtained from this bioassay is in agreement with that reported by several workers (e.g. Chu et al., 1973, Aspinall and Paleg, 1976; Buhl and Stewart, 1983; Stewart et al; 1986; Ueda et al; 2001, and Votberg \& Stewart, 2001). Wilting caused an increased conversion of glutamate to other products. In nonstarved leaves, conversion to organic acids as well as to proline was increased. In starved leaves, wilting caused an increase in the conversion of glutamate to glutamine, aspartate, asparagines, and organic acids.

Estimation of the amino acid proline as an indicator for salinity and/ or drought tolerance presented an evidence that the tested genotypes displayed a wide range for this character, and accordingly it might be employed and used in evaluative purposes and breeding program. Assessment of genotoxicity of Stevia extract has been precisely carried out (Seehy, 2003), who employed a variety of short-term genotoxic bioassayes using yeast, mice, rat and human lymphocytes. It was found that this extract is negative clastogen, negative mutagen on yeast, mice, rate and human genome.

Acknowledgement: Special thanks to Dr. M. A. El-Seehy Professor of molecular cytogenetics for critical reading of the manuscript.

\section{REFERENCES}

Aspinall, D. and G. Paleg (1976). Effect of water stress on praline synthesis from Radioactive precursors. Plant physiol. 58: 399-401.

Buhl, M. B. and C. R. Stewart (1983). Effect of Nacl on praline synthesis and utilization in excised Barley leaves. Plant physiol. 72: 664-667.

Chu, T. M; D. Aspinall and G. Paleg (1973). Stress metabolism. vl. Temperature stress and the accumulation on of praline in Barely and Radish. Bio. Sci. 26: 319-327.

Darlington, C.D. and L.F. La-Core (1962).The handling of chromosomes. Ed. George Allen and Unwin Ltd., London.

Eid, S. E., (1958). Preservation of stainability of the chromosomes in material fixed in acetoalcohol. Egypt J. Bot., 1: 93-96.

Eid, S.E., (1963). A safe method for making squash preparations permanent. Alex. J. Agric. Res., 11: 213-215. 
El- Sharnoby, H.M(2009) Genetical studies on Stevia plant as a matural sweetner: "cytogenetical and biochemical Studies" . MSc. Thesis, Fac. Of Agric. Alex. University.

Fachinetto, J.Maria, H. D.Laughinghouse, A. C. F.Da Silva and S. B. Tedesco (2008). Variability of the chromosomal number and meiotic behavior in population of Bidens pilosa L. (Asteraceae) from southern Brazil. Caryologia. 61: 2, 164 -169.

Ferreira, C. M. and Walter Handro (1988b). Production, maintenance and Plant regeneration from cell suspension cultures of Stevia rebaudiana Bertoni. Plant Cell Reports 7: 123-126.

Ferreira, C. M., and W. Handro (1988a).Stevia rebaudiana mature leaf culture, propagation, colchicines effect and Culture medium optimization.PlantaMedica. 54: 2, 157-160.

Frederico, A. P., P. M. Ruas., M. A. Marin Morales., C. F. Ruas., and J. N. Nakajima (1996) Chromosome studies in some Stevia Cav. (Compositae) species from southern Brazil. Brazilian Journal of Genetics. 19: 4, 605-609.

Hamilton, P. B. (1962). Ion exchange chromatography of ammonia acids. Micro-determination of free ammonia acids in serum. Ann. N. Y. Acid. Sci. 102, 55-75.

Handro, W., C. M. Ferreira., and E. I. S. Floh (1993). Chromosomal variability and growth rate in cell suspension cultures of Stevia rebaudiana (Bert.). Plant.Sci. 93, 1-2, 169- 176.

Hata S., T. Yomo., and S. Fujita (2001).Breeding of triploid plants of Stevia (Stevia rebaudiana Bertoni).with high rebaudioside A content. Japanese Journal of Tropical Agriculture. 45: 4, 281-289., 26 ref.

McClintock, B., (1929). A method for making aceto carmine smear permanent. Stain. Tech. 4: 53-56.

Megeji NW, et al. (2005) Introducing Stevia rebaudiana, a natural a zero calorie sweetener. Institute of Himalayan Bioresource on fertility in rats. J. Ethnopharmacol 67: 157- 161

Miyagawa, H., N. Fujioka., H. Kohda., K. Yamasaki., k. Taniguch., and R. Tanaka (1986). Studies on the tissue culture of Stevia rebaudiana and its components. $(\Pi)$. Induction of shoot primordial. PlantaMedica. 4: 321-323.

Nakajima, J. N., and R. Monteiro (1995). Uniformity of pollen grains in 18 Brazilian species of Stevia Cav. (Eupatorieae, Asteraceae). Natuealia. 20: 9- 19.

Seehy, M.M. (2003) Molecular Genetic Study on an Economic Plant. MSc. Thesis, Fac. Of Agric. Alex. University.

Stewart, C. R. (1978). Role of carbohydrates in praline Accumulation in Wilted Barley leaves. Plant Pysiol. 61: 775-778.

Stewart, C. R; G. Voetberg and P. J. Rayapati (1986). The Effects of BenzyladenineCycloheximide, and Wilting-Induced Abscisic Acid and praline Accumulation and Abscisic Acid and Salt-Induced praline Accumulation in Barely leaves. Plant Physiol. 82: 703-707.

Uddin S Mohd, et al. (2006) In vitro propagation of stevairebaudianaBertoni in Bangladesh. African j. Biotech 5 (13): 1238 - 1240 
Ueda, A; W. Shi; K. Sanmiya; M. Shono and T. Takabe (2001). Functional Analysis of Salt-Inducible praline Transporter of Barley Roots. Plant and Cell Physiol. 42: 1282-1289.

Vanessa M. de Oliveira., Eliana R. Forni Martins., Pedro M. Magalhães., and Marcos N. Alves (2004).Chromosomal and morphological studies of diploid and polyploidcytotypes of Stevia rebaudiana Bertoni (Eupatorieae, Asteraceae) Genet.Mol. Biol. vol.27 no.2

Voetberg, G. and C. R. Stewart (2001). Steady state proline levels in SaltShocked Barely leaves. Plant Physiol. 76: 567-570.

Watanabe, K., T. Yahara., A. Soejima., and M. Ito (2001).Mexican species of the genus Stevia (Eupatorieae, Asteraceae) chromosome numbers and geographical distribution. Plant Species Biology 16 (1) 49-68.

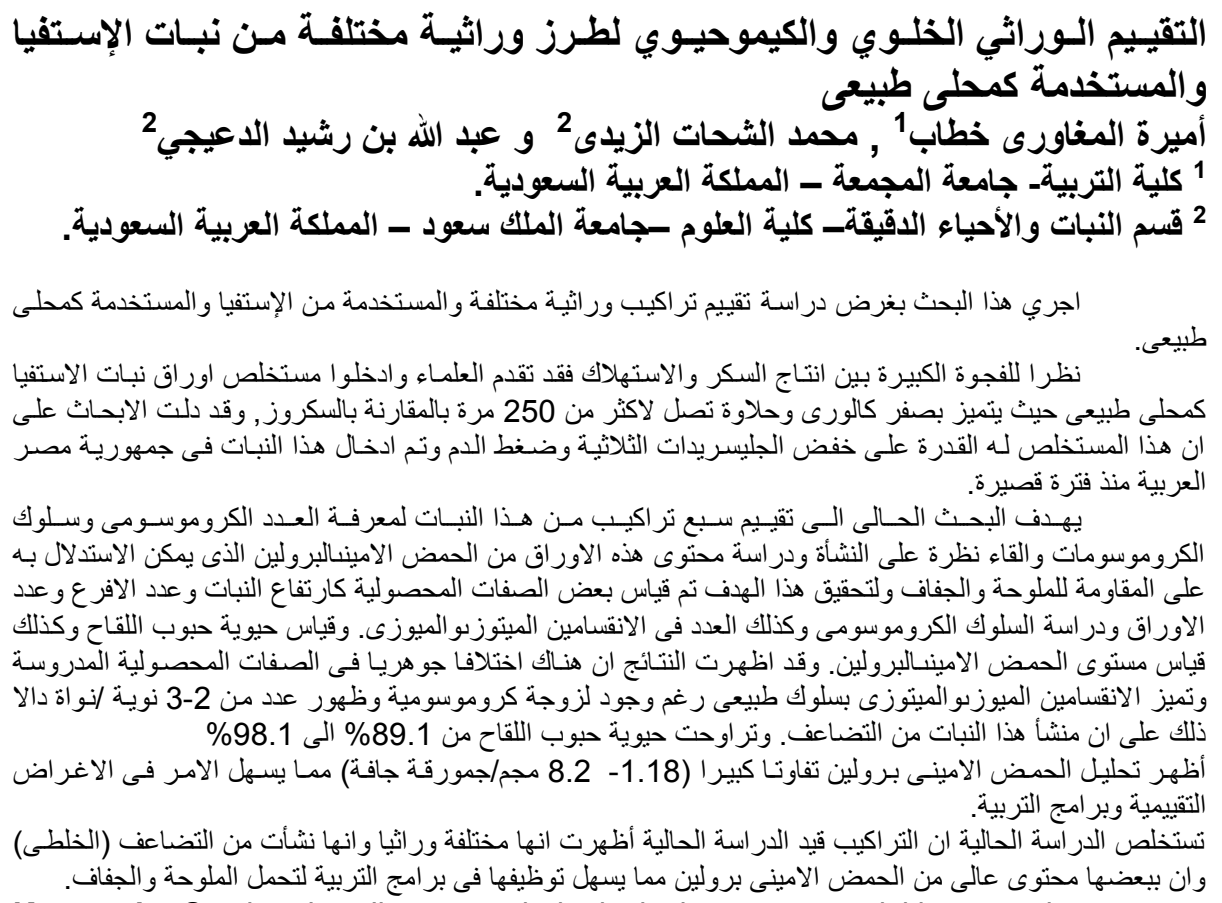

Keywords: Stevia rebaudiana, morphological, chromosome stickiness and tappetum.

كلية الزراعة - جامعة المنصورة

كلية الزراعة - جامعة الأسكندرية

\section{قام بتحكيم البحث}

أ. أد / خليفه عبد المقصود زايد

أ.د / محمد عبد الباعث الصبحى /لمد زايد 